\title{
Medmennesker på nett
}

\author{
Roy-Åge Kristiansen og Mariell Lian intervjues av Ingeborg Vea.
}

Flere frivillige organisasjoner har lang erfaring med å drive krise- og hjelpetelefontjeneste. I de siste årene har noen av dem også etablert et Internett-tilbud til mennesker som ønsker hjelp i en vanskelig livssituasjon. Vi har intervjuet to hjelpere som forteller om hvilke utfordringer og fordeler nettkommunikasjon gir, og om hvordan de frivillige møter den som søker hjelp. - Flere SOS-meldinger enn telefonsamtaler berører selvmordstanker, selv om den akutte faktoren ofte mangler i meldingene, forteller Roy-Åge Kristiansen i Kirkens SOS. Også Røde Kors får ofte henvendelser om selvmordstanker, forteller Mariell Lian.

Roy-Åge Kristiansen har jobbet som frivillig for Kirkens SOS i tre år, omtrent like lenge som SOS-meldingstjenesten har fungert. Som frivillig besvarer han både telefoner og SOS-meldinger. Selvmord er ofte et tema i meldingene, forteller Kristiansen.

- Andre temaer som går igjen i SOS. meldingene er selvskading, relasjonsproblemer og spiseforstyrrelser.

Kristiansen tror det har med alderen på innsenderne å gjøre.

- De som sender meldinger, er yngre enn de som ringer. Jeg tipper gjennomsnittsalderen ligger på rundt 20 år. Innringerne er gjerne eldre personer, og ensomhet er et viktig tema.

Kropp og seksualitet er vanlige temaer i henvendelsene til R $\varnothing$ de Kors-telefonen for barn og ungdom, som fra august i 2005 også har tilbudt meldingstjeneste via nettsiden K ors på halsen.

- Barn og ungdom er opptatt av forelskelse, kjærlighet og kropp. Mange lurer på om de er normale, forteller prosjektleder Mariell Lian.

Også Røde Kors opplever at problemstillingene er tyngre i meldingene enn i telefonsamtalene, og făr ofte henvendelser om selvmordstanker.

- Mange skriver at de "ikke orker mer" eller at de er "lei av alt". Noen skriver at de "bare vil d $\varnothing$ ". Du sier ikke det like lett over telefonen, tror Lian.

Kommunikasjon på nett gir andre utfordringer enn telefonsamtaler:

- Når vi svarer, gjør vi det ut fra ordene til den som har skrevet inn. Vi kan ikke

"N ettkommunikasjon er ikke en halv samtale, men fullverdig kommunikasjon, og i noen henseender sterkere, tydeligere og dypere enn telefonsamtaler og møter ansikt-til-ansikt." skrive tilbake og få oppklaringer eller sjekke ut eventuelle misforståelser, og vi risikerer å svare på noe annet enn det innsenderen egentlig spør om. Svarene vi gir kan åpne for nye muligheter og spørsmål, men vi har ingen anledning til å sjekke ut tankene og refleksjonen svaret setter i gang hos mottakeren.

Da er det god hjelp å ha rammer og metoder for hvordan vi svarer, sier Lian.

Ungdommene i fokusgruppene til Røde Kors-telefonen sier at de foretrekker å skrive meldinger når tårene renner, mens det er lettere å ringe når ordene blir mange.

Kristiansen synes nettkommunikasjon gir flest fordeler:

- Mange hindringer er borte på nettet: sjenanse, klasseskiller, hvilken arena vi møtes på osv. Nettkommunikasjon er ikke en halv samtale, men fullverdig kommunikasjon, og i noen henseender sterkere, tydeligere og dypere enn telefonsamtaler og møter ansikt-til-ansikt. Fra å tenke at vi må få dem som sender meldinger til å ringe, tenker jeg nå tvert om. Meldinger har mindre "st $\varnothing y$ ". Over telefonen går innringerne gjerne flere runder før de får sagt det de har på hjertet, mens meldingene gjerne er mer bearbeidet når avsenderen trykker på send-knappen. Kommunikasjon via meldinger er også mer symmetrisk: Innsenderen og vakten som svarer, er likeverdige. Det oppleves ikke alltid sånn i direkte møte eller over telefonen, sier Kristiansen.

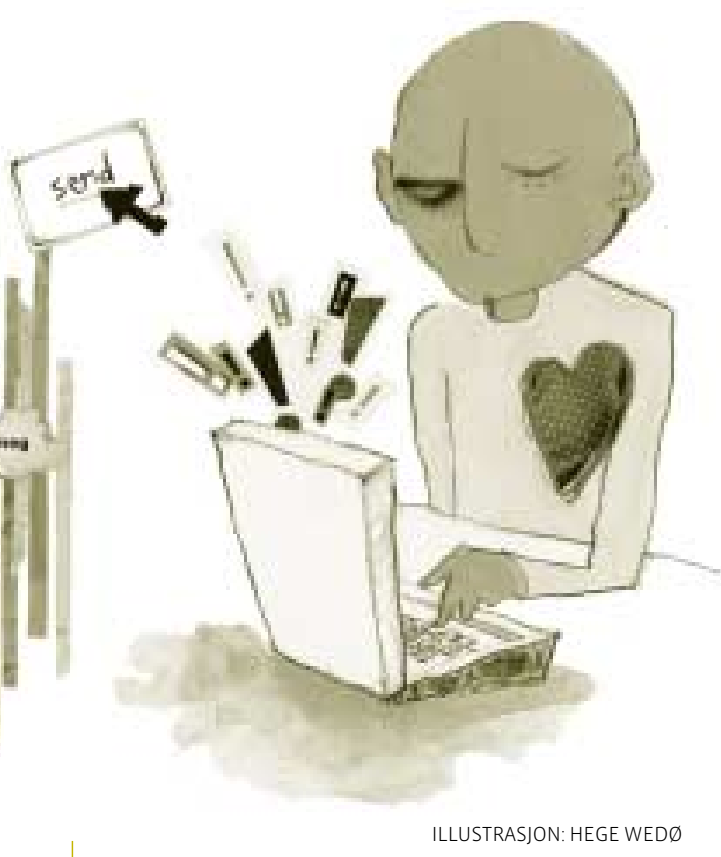

" $N$ år jeg sitter foran maskinen, føler jeg at jeg har makt over tingene, og jeg blir ikke redd for å skrive om det jeg ellers er redd for."

"Jeg bruker anonymiteten til å forsøke à være den jeg er. Jeg har lettere for å være ekte hvis ingen vet hvem jeg $\mathrm{i}$ virkeligheten er. I virkelighetens verden føler jeg at jeg alltid skal gjøre som de fleste mennesker rundt meg."

(Sagt om det å kommunisere på nett, Lønsted \& Schramm, 2001)

\section{Ikke et akutt-tilbud}

Kirkens SOS-meldinger og nett-tjenesten K ors på halsen fungerer som en slags "forsinket chat", hvor innsenderen logger seg inn på en nettside med brukernavn og passord. Innsenderne velger hvilket navn de $\varnothing$ nsker å benytte, og oppgir ikke sin identitet eller e-postadresse. SOSmeldingene har en svargaranti på 24 timer, mens nett-tjenesten K ors på halsen garanterer svar i løpet av 48 timer. 
-24-timersregelen kan være et problem i akutte situasjoner. M en vi får ikke mange akutte meldinger, og når de dukker opp blir de i praksis håndtert mye raskere enn i løpet av 24 timer. Vi forsøker med jevne mellomrom å se gjennom innkomne mel dinger for å skille ut hastemel dingene, sier Kristiansen. I K ors på halsen kommer det også akutte meldinger av og til, men svargarantien på 48 timer signaliserer tydelig at denne nett-tjenesten ikke er et akutttilbud, tror Lian.

Skriveprosessen er for mange terapi i seg selv, påpeker både Kristiansen og Lian. - Det at de skriver til oss, hjelper dem med å sette ord på hvordan de har det. $\mathrm{N}$ oen skriver side opp og side ned, i jegform som til en dagbok, sier Lian.

Skrivingen innebærer en eksternalisering av problemene fordi det skrevne er et produkt, noe utenfor meg selv, på en helt annen måte enn det jeg sier. Derfor kan JEG fortsatt være problemet når jeg snakker om problemet, men etter å ha skrevet om problemet en stund, blir PRO BLE M ET problemet. Dermed skapes avstand til den dominerende, negative historien, den som har formet livet til nå. D e vonde opplevelsene er ikke oppkonstruerte. Vi må erkjenne at de er virkelige, men menneskets dominerende historie kan omskrives. $\mathrm{N}$ år man utvikler en ny måteå kommunisere på, kan problemene bevege seg mot oppløsning (Lønsted og Schramm, 2001).

I Kors på halsen følger ikke de frivillige historikken til innsenderne.

- Ved å føl ge opp meldinger over tid er faren for å bevege seg over i behandlerrollen stor. Dette ligger utenfor rammene for vårt arbeid, sier Lian .

I Kirkens SOS kan korrespondansen følges 30 dager tilbake i tid, forteller K ristiansen.

- A vsenderne i KirkensSO S varierer, noe innsenderne er klar over. Vi underskriver med "Jo", som er et felles navn for alle de frivillige. På den måten unngår Kirkens SO $S$ at tilknytningen til én medarbeider blir problematisk for innskriveren. $\mathrm{N}$ oen innsendere skriver til oss jevnlig i flere måneder, sier Kristiansen.

"J eg forsøker å gå inn i mørket, være der sammen med dem og akseptere dem der de er."
"Vi tilbyr dem et rom hvor de kan sette ord på ting og dele dette med et annet menneske som de kan stole på."

\section{Gir ikke råd}

De frivillige i Kirkens SOS er ikke fagpersoner, men medmennesker. Deres rolle beskrives med tre stikkord: De skal se, favne og tåle, forteller K ristiansen.

- Jeg opplever ikke meg selv som hjelper eller rådgiver, men som en som betingelsesløst er til stede i det innringerne eller innsenderne står i. Jeg forsøker å gå inn i mørket, være der sammen med dem og akseptere dem der de er. I stedet for å bli for løsningsorientert forsøker jeg å orke å høre alt de har på hjertet. For meg er det kristen nestekjærlighet. Da Jesus spiste sammen med den forhatte tolleren og pengeutpresseren Sakkeus, sa han ikke et ord om at han måtte forandre seg. M en Sakkeus opplevde å bli sett og akseptert, og val gte selv å endre sin livsførsel. For at mennesker skal endre seg, må endringen komme innenfra. M ennesker har store ressurser i seg - selv om vi ikke gjør et poeng ut av det overfor mennesker $\mathrm{i}$ fortvilte situasjoner, sier Kristiansen.

Selv om de frivillige ikke gir direkte råd, kan de ved akutte situasjoner be innsenderen eller innringeren om å ringe etter hjelp.

- Vi har anledning til å ringe A M K sentralen (A kutt M edisinsk Kommunikasjonssentral) , for eventuelt å tilkalle en ambulanse. J eg er også tydelig på at jeg ikke ønsker at innringeren eller innsenderen skal ta livet sitt, sier Kristiansen.

I Kors på halsen er de frivillige bevisste på at de skal være "voksne i møte med barn", forteller Lian:

- Barna og ungdommene som henvender seg til oss, har et behov for at noen voksne tar seg tid til dem. Vi tilbyr dem et rom hvor de kan sette ord på ting og dele dette med et annet menneske som de kan stole på. Vår rolle er å være medmennesker, anerkjenne deres følelser, forsøke å gi hăp og vise muligheter. $M$ en hva de skal gjøre, vil vi helst at de skal finne ut av selv, sier Lian.

\section{Kirkens SOS-meldinger}

- Etablert i 2003

- Besvares av frivillige i Kirkens sos

Driver ikke terapi

Svargaranti på 24 timer

- Kvalitetssikring: Alle frivillige får opp læring, svar på meldinger leses alltid gjennom av to frivillige før det sendes

- Anonymitet: Innsenderne sender melding via nettside hvor de selv velger passord og brukernavn. Meldingene sendes ikke med e-post-adresse som kan avsløre identitet.

- Kirkens SOS har utviklet et videregående kurs innen behandling av SOS-meldinger. Dette er det første av sitt slag i Norden.

- Av 5000 henvendelser på nett i 2005 var 90 prosent fra kvinner (av de som tilkjennega kjønn)

- 90 prosent av innsenderne i 2005 var under 30 år. Blant disse var halvparten mellom 10 og 19 år.

- Kvinner skriver oftere om selvmord enn menn. 36 prosent av de kvinnelige innsenderne i 2005 ble vurdert å ha fra middels til høy risiko for selvmord. Tilsvarende tall for menn var 26 prosent.

- Nettside: www.kirkens-sos.no

\section{Røde Kors' nett-tjeneste} "Kors på halsen":

- Etablert sommeren 2005

- Besvares av frivillige for Røde Korstelefonen for barn og ungdom

- Svargaranti innen 48 timer

- Driver ikke terapi

- Kvalitetssikring: Alle svar på meldinger kvalitetssikres av en ansatt før det sendes. Egen opplæring på nett tjenesten er under utvikling.

- Anonymitet: Samme løsning som Kirkens SOS-meldinger

- Hyppige temaer: Selvskading, selvmord, kropp, seksualitet, forelskelse

- Gjennomsnittsalder: 15 år (tjenesten er for barn og ungdom opptil 18 år), 75 prosent av innskriverne er jenter.

- Nettside: www.korspahalsen.no

Referanse

Vilhelm Lønsted \& M ads Schramm:

"www.nærkontakt.net"

Dansk psykologisk forlag, 2001 